\title{
Adoption Status and Perception of Farmers on Improved Tef Technology Packages: Evidence from East Gojjam Zone, Ethiopia
}

\author{
Atrsaw Anteneh Mihretie $\mathbb{D}^{1},{ }^{1}$ Girmachew Siraw Misganaw $\mathbb{D}^{2}$, \\ and Negussie Siyum Muluneh (D) $^{3}$ \\ ${ }^{1}$ Department of Rural Development and Agricultural Extension, College of Agriculture and Natural Resource, \\ Mekdela Amba University, Germame, Ethiopia \\ ${ }^{2}$ Department of Rural Development and Agricultural Extension, College of Agriculture and Environmental Sciences, \\ Bahir Dar University, Bahir Dar, Ethiopia \\ ${ }^{3}$ Sirinka Agricultural Research Center, Woldia, Ethiopia \\ Correspondence should be addressed to Girmachew Siraw Misganaw; girmachew2011@gmail.com and Negussie Siyum Muluneh; \\ negussiese@gmail.com
}

Received 11 June 2021; Accepted 28 December 2021; Published 2 February 2022

Academic Editor: İbrahim Kahramanoğlu

Copyright (C) 2022 Atrsaw Anteneh Mihretie et al. This is an open access article distributed under the Creative Commons Attribution License, which permits unrestricted use, distribution, and reproduction in any medium, provided the original work is properly cited.

\begin{abstract}
Tef is a major staple crop in Ethiopia and Eritrea. Many improved Tef varieties were released from the Ethiopian research institute in the past three decades. Information on the farmers' adoption status and perception on released improved Tef technology have paramount importance for launching new and modifying Tef technology packages. However, such information is meager in Ethiopia. Therefore, this study was conducted to assess farmers' status and perception of improved Tef technologies. A multistage random sampling technique was employed to select sample of $224 \mathrm{Tef}$ grower farmers. The results were interpreted and discussed using descriptive and inferential statistics. The result indicated that farmers in the study area found at the medium level of adoption of Tef production technology (i.e., the average adoption index is 0.43 ). The findings also confirm that farmers perception towards the relative advantages of improved Tef varieties shows that high grain yield, good germination, early mature, and disease resistance capacity were perceived as the most crucial attributes of improved Tef varieties, whereas straw quality and tolerance to lodging were perceived as the least important attributes of the technology. Therefore, efforts and commitments to be expected from plant breeders and genetic specialists to reduce lodging of Tef through hybridizing semidwarf Tef varieties.
\end{abstract}

\section{Introduction}

The agricultural sector continues to play a dominant role in the development and growth of most African nations. Ethiopia is one of the most populous countries on the continent. In this regard, the agricultural sector is the mainstay of the economy and catalyst for the entire development of the country [1]. It accounts for about $34 \%$ of GDP [2] and $66.12 \%$ of employment [3].

Cereal crops are the main cultivated crop in Ethiopia. It contributes $81.39 \%$ and $87.97 \%$ in acreage and production for total crops, respectively, in the 2018/19 cropping season [4]. Tef (Eragrostis Tef) is a major cereal crop and extensively cultivated in most of the agroecological zones of Ethiopia and Eritrea [5]. In Ethiopia, a total of 3.07 million hectares of land were covered in Tef in the 2018/19 cropping season. From this, 54.03 million quintals production was produced. At the country level, Tef contributes $24.32 \%$ for the total cultivated cereal crops and $17.22 \%$ for the total production in the 2018/19 cropping season. In the Amhara region of Ethiopia, Tef contributes $25.4 \%$ in area coverage, $32 \%$ of the total production in the 2018/19 cropping season, and 2.5 million rural households of Ethiopia were engaged in Tef cultivation [4].

Tef is a major staple crop in Ethiopia and Eritrea. It is the most important crop in terms of production value and cultivation area with excellent storage properties, highquality food, and the unique ability to thrive in extreme environmental conditions [1]. Besides being used to make the Ethiopian cultural food Injera (Injera is "pancake-like 
soft bread in Ethiopia"), its straw is used as a feed for livestock and binder of mud for house construction in rural and semiurban parts of Ethiopia [6]. Currently, Tef cultivation is spreading to other parts of the world (i.e., Australia, Canada, the Netherlands, South Africa, and the USA). Abroad, it is used for gluten (gluten is a protein found in wheat, barley, and other cereal crops. It is a major cause of lifelong gastrointestinal tract disease, which is called celiac disease. The only effective treatment for celiac disease is the total lifelong avoidance of gluten ingestion. Tef is one of the major gluten-free cereal crops [7]) free food, malting, and brewing [7].

Adoptions of improved technologies and production practices are important drivers of agricultural development in low-income countries like Ethiopia [8]. The Ethiopian Ministry of Agriculture has attempted to increase the production and productivity of Tef using conventional and modern breeding techniques and improved production technologies. So far, 42 improved Tef varieties and improved agronomic practices were released to the farming community [9].

The adoption of Tef production technology has paramount importance to increase Tef productivity, foster food security, and secure the well-being of smallholder farmers. Information on the farmers' adoption status and perception on released improved Tef technology have a paramount important prerequisite for launching new and modifying existing Tef technology packages. Such useful information is however meager in Ethiopia. Therefore, this study was undertaken to assess farmers' status and perception of improved Tef technologies in the West Gojjam zone, Ethiopia.

\section{Materials and Methods}

2.1. Description of the Study Area. Yilmana Densa district is located in the West Gojjam administrative zone about $42 \mathrm{Km}$ far from the capital city of the Amhara region, Bahir Dar (Figure 1). According to Yilmana Densa Agriculture and Rural Development Office (YDARDO) report, Yilmana Densa district has 30 rural kebeles and 4 town kebeles. The main farming system in the study area is mixed farming including crop production and livestock. The majority of farmers practice a traditional way of crop production system such as plowing in oxen, harvesting in sickles, threshing in livestock and human power, sowing in broadcast, and poor land management. Tef, wheat, maize, potato, barley, field pea, and finger millet are the major crops grown in the district.

2.2. Sampling Technique and Sample Size. A multistage random sampling technique was employed to select sample households (in this study, a household is defined as all persons living in the same house and sharing their meals together) for this study. In the first stage, from the total of 19 potentials (out of 35 rural kebeles) Tef producer kebeles, three kebeles were selected using a simple random sampling technique. In the second stage, sample respondents were selected using a systematic random sampling technique from the selected kebeles.
The sample size from each kebele was taken through population proportion (see Table 1). Availability of sample frames at the kebele agricultural office and homogeneous socioeconomic characteristics of the population were the main reasons for using this type of random sampling technique [10].

There are many rules-of-thumb used to determine the representative sample size to conduct analysis. In this study, Kothari's [11] sample size determination was employed to select a representative sample size. The main reasons to use this sample determination are: first, it is the latest sample determination method, and second, it considers two groups, failure (nonadopter) and success (adopter). There are two situations to consider $p$ (population proportion of success).

First, if some approximation is known (from a previous study) that value can be used in the formula. Second, if no approximation is known, use 0.5 . This value will give a sample size sufficiently large to guarantee an accurate prediction, given the confidence interval and the error of the estimate. The reason is that when each is 0.5 , the product is at maximum [10]. Based on the following equation, $224 \mathrm{Tef}$ grower farmers were selected using population proportion for each kebele:

$$
n=\frac{z^{2} \cdot p \cdot q \cdot N}{e^{2}(N-1)+z^{2} \cdot p \cdot q}
$$

where we have the following:

(1) $n=$ estimated sample size

(2) $e=$ the allowable error, where $e=0.05$

(3) $N=$ total Tef grower farmers $(N=2584)$

(4) $p=$ the estimated proportion of an adopter that is present in the population, which is 0.8 (from a previous study by Tamir [12])

(5) $q=$ the population proportion of nonadopter in the population. $q=1-\mathrm{p}$, where $q=1-0.8$; therefore, $q=0.2$

(6) $\mathrm{Z} \alpha / 2=$ standard variate for given confidence level (as per normal curve area). It is 1.96 for a $95 \%$ confidence interval

2.3. Source and Type of Data Collection. In this inquiry, crosssectional data were used for achieving the objective of the study. Data were collected from primary and secondary sources. Primary data were collected from the sample farmers using a structured interview schedule from $224 \mathrm{Tef}$ grower sampled farmers. Primary data such as demographic, socioeconomic, institutional, farmer's perception, and plotlevel data were collected using Kobo Toolbox (KoBo Toolbox is a free open-source tool for mobile data collection, available to all. It allows collecting data in the field using mobile devices such as mobile phones or tablets, as well as with computers) software. The data were collected using qualitative and quantitative approaches from sampled farmers. Information was gathered from the kebele administrative body, development agent, and district agricultural officers to capture supplementary information and to observe the validity of information from the household 


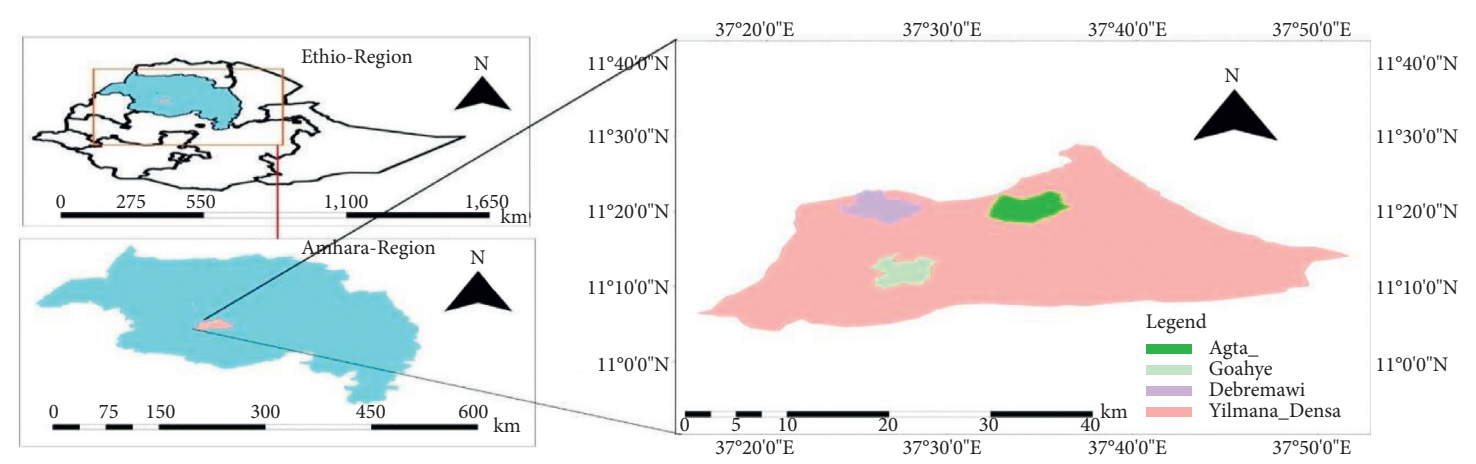

Figure 1: Location of the study area.

survey. Secondary data such as theories and models, empirical evidence, and supplementary data to primary data were collected from the journal article, previous studies, agricultural office manuals, proceedings, and NGO reports.

2.4. Methods of Data Analysis. After the data was collected, the data were arranged, coded, managed, and analyzed by using STATA version 15.1. The results were interpreted and discussed using descriptive and inferential statistics. Descriptive statistics such as mean, standard deviation, percentage, and frequency distribution were used to describe the socioeconomics, institutional, and demographic characteristics of the respondents. Furthermore, inferential statistics were used to compare the means (i.e., one-way ANOVA) between adoption categories.

2.4.1. Status of Adoption of Tef Technology Packages. To know the aggregate adoption level of Tef production technology, first, it was listed for the main components of the technology packages based on the Tef production manual, which was prepared by the Amhara National Regional State Bureau of Agriculture collaborated with ATA and EIAR in [13] for package study, giving equal weights for each package not acceptable because some components are easy to implement, while others are difficult to implement. In addition, all components do not have equal contributions to specific crop production.

Many scholars such as Mulugeta [14], Wuletaw and Daniel [15], Ogunya et al. [16], and Julius and Jimoh [17] had given weight to each package to obtain the intensity of adoption of a given technology. Therefore, this study has given different weights for each package of Tef production technology (see equation (2). Based on the weight, the Tef grower farmer's adoption level was calculated. Accordingly, the adoption index of the technology was calculated as follows:

$$
A I i=\sum\left\{\left(\frac{A T i}{R T i} x I S i\right)\right\},
$$

where $A T i$ is the level or number of packages (plowing frequency, seed type, crop rotation, fertilizer rate, seed rate, sowing method, and weeding frequency) of the $i^{\text {th }}$ farmer applied. $R T i$ is the recommended level or number of
TABle 1: Sample size distribution.

\begin{tabular}{lccc}
\hline No. & Kebele & Total Tef grower population & Sample \\
\hline 1 & Agita & 1,006 & 87 \\
2 & Goshiye & 758 & 65 \\
3 & Debremawi & 820 & 72 \\
\hline Total & & 2,584 & 224 \\
\hline
\end{tabular}

Source: computed from kebele records, 2020.

packages farmers ought to apply, ISi is the proportion of score (weight) for each package. AIi is the adoption index of the $i^{\text {th }}$ farmer.

As already explained above, researches conducted on agricultural technology adoption had been using weight to calculate adoption intensity. For instance, Mulugeta [14] used weight to calculate the intensity of the adoption of old coffee stumping technology packages. Wuletaw and Daniel [15] give a proportion score to calculate the adoption intensity of Malt-barley. Research conducted by Ogunya et al. [16] used weight for each package to calculate the adoption intensity and level of Nerica rice varieties in Ogun, Nigeria. Julius and Jimoh [17] give weight for each technology packages to calculate the intensity of adoption of cocoa production technology packages in Ekiti State, Nigeria. They calculated the weight from sample respondents. Hence, this study computed the proportion score (weights) of Tef production technology packages from district agricultural experts and model farmers.

2.4.2. Farmer's Perception towards Improved Tef Technology Packages. Farmers' perception towards improved Tef varieties and row planting was analyzed using five-point Likert scales as strongly agree (5), agree (4), undecided (3), disagree (2), and strongly disagree (1). The least favorable degree is given the least score (1), and the most favorable is given the highest score (5). The study used relative importance index (RII) analysis to rank the attributes of improved Tef varieties and row planting methods according to their advantages and disadvantages. The following formula was used to determine the relative index [18].

$$
\mathbf{R I I}=\frac{\sum \mathbf{W}}{\mathbf{A N}}=\frac{5 \mathbf{n} 5+4 \mathbf{n} 4+3 \mathbf{n} 3+2 \mathbf{n} 2+1 \mathbf{n} 1}{5 \mathbf{N}},
$$


where RII is the relative importance index, $A$ is the highest weight, $N$ is the sample size, and $W$ is the weight as assigned by each respondent on a scale of one to five with one implying the least and five being the highest. Scales for measuring farmers' perceptions were given from one to five. One implies the least, and five is the highest.

\section{Results and Discussion}

3.1. Demographic Characteristics. As shown in Table 2, from the total sample respondents, $85.27 \%$ were male-headed, while the remaining $14.73 \%$ were female-headed. Another notable result is that the mean age of the sample household heads was found to be 44.63 years with a standard deviation of 12.05. This shows that majority of the household heads were found at productive age.

The average family size of the household was 5.16 persons. The mean labor force based on the conversion factor of man-day equivalent was 2.76. This shows that over half of household members can work on the farm. In the case of the Yilmana Densa district, farmers starting their farming at the early age $18 \mathrm{~s}$. Due to this, the majority of the household heads have solid Tef farming experience (24.50 years). Educated farmers are taught to adopt and peruse in using improved technology. The average education level of sample households was 1.35 with a standard deviation of 1.327 . This implies farmers in the study area are not well educated.

3.2. Current Status of Farmers on the Adoption of Tef Technology Packages. The agronomic practice of improved Tef production technology package contains land preparation, crop rotation, improved seed, sowing method, planting date, seed rate, rate of fertilizer application, the timing of fertilizer application, weeding frequency, disease prevention, pest prevention, harvesting time, threshing method, and storage system. However, all the packages were not included in this study to calculate the adoption index because it is difficult to get reliable data for some packages (i.e., sowing date and harvesting). Furthermore, some packages are included in other packages. For instance, the recommendations of disease and pest prevention are integrated under management such as plowing frequently, deep plow, applying crop rotation, and use of improved seed. Therefore, those packages are included in crop rotation, improved seed, and plowing frequency. Eventually, this study included plowing frequency, crop rotation, rate of fertilizer application, seed type, seed rate, sowing method, and weeding frequency to know adoption status and intensity of Tef production technology in the study area.

The actual adoption categories were categorized into four groups such as nonadopter, low adopter, medium adopter, and high adopter based on the adoption index. The index score is $0.00,0.01-0.33,0.34-0.66$, and $0.67-1.00$, which represents none, low, medium, and high adopters, respectively. Similar studies, Endeshaw [19], Bosena and Susie [20], and Dawit and Gemechu [21], used similar techniques.
As shown in Table 3, from the total sample households, $21.43 \%, 3.13 \%, 69.64 \%$, and $5.80 \%$ were categorized under none, low, medium, and higher adopter of Tef production technology packages, respectively. The result indicates that the average adoption index was 0.43 with a standard deviation of 0.24 . This implies that farmers in the study area are categorized as medium adopters. There is a significant mean difference between adoption categories in the adoption index at less than $1 \%$ level of significance.

According to Table 4, from the total sample households, $78.57 \%$ of farmers were using improved Tef varieties. Evidence from the key informants in Goshiye kebele indicates that farmers in the sample kebele accessed improved seed from Avolla Goshiye community-based seed enterprise since 2014. Due to the fact, in the study area, majority of farmers are used improved Tef seed. Contrary to this, only $4.91 \%$ of the sample households applied the Tef row planting method in their Tef plots. Evidence from farmers' perception towards the row planting method indicates that farmers do not apply this package due to its low straw quality for the livestock feeding, more time consumption, and high labor consumption even they are accepted better yield, reduced seed cost and convenient for weeding attributes of the package. The result is consistent with the findings of Bart et al. [1].

The recommendation of seed and fertilizer rates for Nitosols and Vertisols are different. As shown in Table 4, $79.61 \%$ and $79.01 \%$ of the farmers applied improved Tef seed in their Nitosols and Vertisols, respectively. Another notable result is that $97.55 \%$ and $98.77 \%$ of the sample households applied urea and NPS/NPSB fertilizer for Nitosoils, respectively. Similarly, $93.87 \%$ and $93.25 \%$ of the farmers who have Vertisols applied urea and NPS/NPSB, respectively. This implies that farmers applied inorganic fertilizer almost in all their Tef plots. In addition, the adoption status of weeding and plowing frequency was found that the sample households were adopters (100\%), whereas only $91.07 \%$ of the sample households were applied crop rotation in their Tef plots. This implies that the majority of farmers are applied crop rotation to reduce weed and improve soil fertility. According to Table 4, there is a significant mean adoption index difference between adopter categories in all the Tef packages at a $1 \%$ level of significance.

3.2.1. Adoption of Improved Tef Varieties. As illustrated in Table 5, the average area allocated in improved Tef seed was 0.31 ha with a standard deviation of 0.21 , whereas the average area covered under local varieties was 0.16 ha with a standard deviation of 0.15 . This implies that in the study area, the majority of sample households covered their Tef plot in improved seed rather than local seed.

Asgori, Magna, Quncho, Dukem, Kena, Etsub, Dima, Kora, Dagm, Ngus, Tesfa, Flagot, Avolla, and Areka 01 improved Tef varieties are recommended for the optimum rainfall areas. Relatively early maturing varieties such as Tsedey, Gemechis, Simada, Hibr-1, Zobel, Workyu, and Boset are recommended for terminal low moisture and stress areas. Glmbichu and Dega Tef are recommended for high land and high moisture areas [13] Yilmana Densa district is categorized under the optimum rainfall areas in the Amhara region [22]. 
TABLE 2: Demographic characteristics of the respondents.

\begin{tabular}{|c|c|c|c|c|c|}
\hline Variables & Obs. & Mean/freq. & Std. dev./percent & Min & Max \\
\hline Age (year) & 224 & 44.63 & 12.05 & 18 & 73 \\
\hline Sex (male) & 224 & 191 & 85.27 & - & - \\
\hline Family size (\#) & 224 & 5.16 & 1.34 & 2 & 10 \\
\hline Marital status (married) & 224 & {$[190]$} & {$[84.82]$} & - & - \\
\hline Education (completed year) & 224 & 1.35 & 2.63 & 0 & 10 \\
\hline Labor (man-day equivalent) & 224 & 2.76 & 0.74 & 1 & 4.5 \\
\hline Tef farming experience (year) & 224 & 24.50 & 11.59 & 1 & 52 \\
\hline
\end{tabular}

Note. '\#' denotes number; value in [ ] indicates frequency and percentage of the categorical variables.

TABle 3: Aggregate farmer's adoption status in Tef technology packages.

\begin{tabular}{|c|c|c|c|c|c|c|}
\hline \multirow{2}{*}{ Adoption category } & \multirow{2}{*}{ Obs. } & \multirow{2}{*}{ Percentage } & \multicolumn{2}{|c|}{ Adoption index } & \multirow{2}{*}{ Std. dev. } & \multirow{2}{*}{$F$} \\
\hline & & & Range & Mean & & \\
\hline Nonadopters & 48 & 21.43 & 0.00 & 0 & 0 & $899.83^{* * *}$ \\
\hline Low adopters & 7 & 3.13 & $0.01-0.33$ & 0.30 & 0.02 & \\
\hline Medium adopters & 156 & 69.64 & $0.34-0.66$ & 0.54 & 0.07 & \\
\hline High adopters & 13 & 5.80 & $0.67-1.00$ & 0.74 & 0.07 & \\
\hline Total & 224 & 100 & 1.00 & 0.43 & 0.24 & \\
\hline
\end{tabular}

Source: computed from own survey, 2020. ${ }^{* * *} p<0.01,{ }^{* *} p<0.05,{ }^{*} p<0.1$, and ns $P>0.1$.

Table 4: Adoption of Tef production technology packages in Yilmana Densa district.

\begin{tabular}{|c|c|c|c|c|c|c|}
\hline Packages & Adoption category & Freq. & $\%$ & Mean adoption index & Std. dev. & $F$-test \\
\hline \multirow{5}{*}{ Area allocation in improved seed } & Nonadopters & 48 & 21.43 & 0.00 & 0.0 & \multirow{5}{*}{$1,202^{* * *}$} \\
\hline & Low adopters & 7 & 3.13 & 0.31 & 0.02 & \\
\hline & Medium adopters & 53 & 23.66 & 0.53 & 0.08 & \\
\hline & High adopters & 116 & 51.79 & 0.91 & 0.11 & \\
\hline & Total & 224 & 100.00 & 0.60 & 0.37 & \\
\hline \multirow{5}{*}{ Row planting } & Nonadopters & 213 & 95.09 & 0.0 & 0.0 & \multirow{5}{*}{$84,580^{* * *}$} \\
\hline & Low adopters & 1 & 0.45 & 0.13 & 0.06 & \\
\hline & Medium adopters & 6 & 2.68 & 0.47 & 0.03 & \\
\hline & High adopters & 4 & 1.79 & 1.00 & 0.0 & \\
\hline & Total & 224 & 100.00 & 0.02 & 0.13 & \\
\hline \multirow{5}{*}{ Seed rate for Nitosols } & Nonadopters & 31 & 20.39 & 0.0 & - & \multirow{5}{*}{$917.33^{* * *}$} \\
\hline & Low adopters & 3 & 1.97 & 0.29 & 0.03 & \\
\hline & Medium adopters & 26 & 17.11 & 0.58 & 0.10 & \\
\hline & High adopters & 92 & 60.53 & 0.77 & 0.07 & \\
\hline & Total & 152 & 100.00 & 0.57 & 0.31 & \\
\hline \multirow{5}{*}{ Seed rate for Vertisols } & Nonadopters & 34 & 20.99 & 0.0 & 0.0 & \multirow{5}{*}{$1,534.76^{* *}$} \\
\hline & Low adopters & 1 & 0.62 & 0.29 & - & \\
\hline & Medium adopters & 38 & 23.46 & 0.62 & 0.03 & \\
\hline & High adopters & 89 & 54.94 & 0.77 & 0.07 & \\
\hline & Total & 162 & 100.00 & 0.57 & 0.31 & \\
\hline Packages & Adoption category & Freq. & $\%$ & Mean adoption index & Std. dev. & $F$-test \\
\hline \multirow{5}{*}{ Urea for Nitosols } & Nonadopters & 4 & 2.45 & 0.6 & 0.70 & \multirow{5}{*}{$45.98^{* * *}$} \\
\hline & Low adopters & 2 & 1.23 & 0.33 & 0.0 & \\
\hline & Medium adopters & 88 & 53.99 & 0.60 & 0.08 & \\
\hline & High adopters & 69 & 42.33 & 0.81 & 0.07 & \\
\hline & Total & 163 & 100.00 & 0.69 & 0.16 & \\
\hline \multirow{5}{*}{ Urea for Vertisols } & Nonadopters & 10 & 6.13 & 0.0 & 0.0 & \multirow{5}{*}{$719.25^{* * *}$} \\
\hline & Low adopters & 0 & 0.00 & - & - & \\
\hline & Medium adopters & 30 & 18.40 & 0.61 & 0.04 & \\
\hline & High adopters & 123 & 75.46 & 0.80 & 0.07 & \\
\hline & Total & 163 & 100.00 & 0.71 & 0.20 & \\
\hline
\end{tabular}


TABle 4: Continued.

\begin{tabular}{|c|c|c|c|c|c|c|}
\hline Packages & Adoption category & Freq. & $\%$ & Mean adoption index & Std. dev. & $F$-test \\
\hline \multirow{5}{*}{ NPS/NPSB For Nitosols } & Nonadopters & 2 & 1.23 & 0.66 & 0.94 & \multirow{5}{*}{$50.23^{* * *}$} \\
\hline & Low adopters & 1 & 0.61 & 0.25 & - & \\
\hline & Medium adopters & 75 & 46.01 & 0.64 & 0.05 & \\
\hline & High adopters & 85 & 52.15 & 0.82 & 0.07 & \\
\hline & Total & 163 & 100.00 & 0.73 & 0.14 & \\
\hline \multirow{5}{*}{ NPS/NPSB for Vertisols } & Nonadopters & 11 & 6.75 & 0.0 & 0.0 & \multirow{5}{*}{$893.04^{* * *}$} \\
\hline & Low adopters & 0 & 0.00 & - & - & \\
\hline & Medium adopters & 97 & 59.51 & 0.63 & 0.05 & \\
\hline & High adopters & 55 & 33.74 & 0.79 & 0.06 & \\
\hline & Total & 163 & 100.00 & 0.64 & 0.19 & \\
\hline \multirow{5}{*}{ Crop rotation } & Nonadopters & 20 & 8.93 & 0.0 & 0.0 & \multirow{5}{*}{$1,871.97^{* * *}$} \\
\hline & Low adopters & 5 & 2.23 & 0.33 & 0.0 & \\
\hline & Medium adopters & 69 & 30.80 & 0.56 & 0.08 & \\
\hline & High adopters & 130 & 58.04 & 0.98 & 0.05 & \\
\hline & Total & 224 & 100.00 & 0.75 & 0.31 & \\
\hline \multirow{5}{*}{ Weeding frequency } & Nonadopters & 0 & 0.00 & - & - & \multirow{5}{*}{$484.63^{* * *}$} \\
\hline & Low adopters & 33 & 14.73 & 0.33 & 0.01 & \\
\hline & Medium adopters & 154 & 68.75 & 0.58 & 0.08 & \\
\hline & High adopters & 37 & 16.52 & 0.90 & 0.09 & \\
\hline & Total & 224 & 100.00 & 0.59 & 0.18 & \\
\hline \multirow{5}{*}{ Plowing frequency } & Nonadopters & 0 & 0.00 & - & - & \multirow{5}{*}{$87.76^{* * *}$} \\
\hline & Low adopters & 2 & 0.89 & 0.25 & 0.0 & \\
\hline & Medium adopters & 3 & 1.34 & 0.62 & 0.0 & \\
\hline & High adopters & 219 & 97.77 & 0.94 & 0.08 & \\
\hline & Total & 224 & 100.00 & 0.93 & 0.11 & \\
\hline
\end{tabular}

Source: own survey data, 2020. ${ }^{* * *} p<0.01,{ }^{* *} p<0.05,{ }^{*} p<0.1$, and ns $P>0.1$.

TABLE 5: Land allocation of improved and local Tef varieties.

\begin{tabular}{lccccc}
\hline Types of Tef variety & Obs. & Mean land (ha) & Std. dev. & Min & Max \\
\hline Improved variety & 224 & 0.31 & 0.21 & 0 & 0.7 \\
Local variety & 224 & 0.16 & 0.15 & 0 & 0.875
\end{tabular}

Source: own survey data, 2020.

As illustrated in Figure 2, the most cultivated improved Tef varieties in the study area were Quncho (70.98\%) and Etsub (7.59\%). The remaining $21.43 \%$ were covered in local Tef varieties (i.e., Davo, Dimbito, Fesho, and Qey Tef). This implies that adopter farmers are cultivating their Tef plots based on the recommendation of improved Tef varieties.

As shown in Table 6, low, medium, and high adopter farmers cover their Tef plots on average 0.14 ha, 0.27 ha, and 0.47 ha on improved seed, respectively. This shows that low, medium, and high adopters covered 36.84\%, 54.00\%, and $90.38 \%$ of their Tef lands with improved seed, respectively. The result implies that high adopters relatively covered their Tef plots widely in the improved seed. There is a significant mean difference between adopter categories with respect to adoption intensity of improved Tef variety at less than $1 \%$ level of significance.

3.2.2. Adoption of Seed Rate. Recommended seed rates for Nitosols and Vertisols are $25 \mathrm{~kg} \mathrm{ha}^{-1}$ and $30 \mathrm{~kg} \mathrm{ha}^{-1}$, respectively [23]. As provided in Table 7, respondents on average applied $26.83 \mathrm{~kg} \mathrm{ha}^{-1}$ and $32.89 \mathrm{~kg} \mathrm{ha}^{-1}$ seed rates for Nitosols and Vertisols, respectively. Another notable result

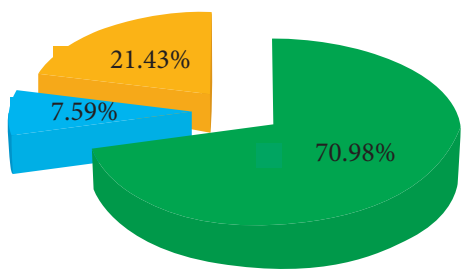

Source: Own survey, 2020

Quncho

Etsub

Local

Figure 2: Types of Tef varieties grown in the study area.

is that on average, low, medium, and high adopters applied $34.16 \mathrm{~kg} \mathrm{ha}^{-1}, 37.04 \mathrm{~kg} \mathrm{ha}^{-1}$, and $32.73 \mathrm{~kg} \mathrm{ha}^{-1}$ seed rate on their Nitosols Tef plots, respectively. Likewise, the low, medium, and high adopters applied on average $34.11 \mathrm{~kg} \mathrm{ha}^{-1}, 48.42 \mathrm{~kg} \mathrm{ha}^{-1}$, and $38.82 \mathrm{~kg} \mathrm{ha}^{-1}$ on their Vertisols Tef plots, respectively. Respondents in the study area applied $26.83 \mathrm{~kg} \mathrm{ha}^{-1}$ and $32.89 \mathrm{~kg} \mathrm{ha}^{-1}$ for Nitosols and Vertisols, respectively. It is worthwhile to note that farmers applied seed rates above the recommended rate. There is a significant mean difference between adopter categories with respect to seed rate in Nitosols and Vertisols at less than $1 \%$ level of significance (see Table 7).

3.2.3. Adoption of Fertilizer. In the study area, farmers use both organic and inorganic fertilizers in their plots. 
TABLE 6: Land area covered by the improved Tef varieties.

\begin{tabular}{|c|c|c|c|c|c|c|}
\hline $\begin{array}{l}\text { Adoption category of improved } \\
\text { variety }\end{array}$ & Freq. & $\%$ & $\begin{array}{c}\text { Mean total Tef land area } \\
\text { (ha) }\end{array}$ & $\begin{array}{c}\text { Mean improved Tef land area } \\
\text { (ha) }\end{array}$ & $\begin{array}{l}\text { Std. } \\
\text { dev. }\end{array}$ & $F$-test \\
\hline Nonadopters & 48 & 21.43 & 0.32 & - & - & $343.43^{* * *}$ \\
\hline Low adopters & 11 & 4.91 & 0.38 & 0.14 & 0.04 & \\
\hline Medium adopters & 49 & 21.88 & 0.50 & 0.27 & 0.07 & \\
\hline High adopters & 116 & 51.79 & 0.52 & 0.47 & 0.11 & \\
\hline Total & 224 & 100.00 & 0.47 & 0.31 & 0.20 & \\
\hline
\end{tabular}

Source: own survey data, 2020. ${ }^{* * *} p<0.01,{ }^{* * *} p<0.05,{ }^{* * *} p<0.1$, and ns $P>0.1$.

TABLE 7: Farmers' adoption status of improved Tef seed rate.

\begin{tabular}{|c|c|c|c|c|c|c|}
\hline Soil type & Seed rate adoption category & Freq. & $\%$ & Mean kg ha ${ }^{-1}$ & Std. dev. & $F$-test \\
\hline \multirow{5}{*}{ Nitosols } & Nonadopters & 31 & 20.39 & 0 & 0 & \multirow{5}{*}{$790.17^{* * *}$} \\
\hline & Low adopters & 3 & 1.97 & 34.16 & 3.81 & \\
\hline & Medium adopters & 26 & 17.11 & 37.09 & 6.24 & \\
\hline & High adopters & 92 & 60.53 & 32.73 & 2.908 & \\
\hline & Total & 152 & 100 & 26.83 & 14.14 & \\
\hline \multirow{5}{*}{ Vertisols } & Nonadopters & 34 & 20.99 & 0 & 0 & \multirow{5}{*}{$2,009.32^{* * *}$} \\
\hline & Low adopters & 1 & 0.62 & 34.11 & - & \\
\hline & Medium adopters & 38 & 23.46 & 48.42 & 2.41 & \\
\hline & High adopters & 89 & 54.94 & 38.82 & 3.48 & \\
\hline & Total & 162 & 100.00 & 32.89 & 17.68 & \\
\hline
\end{tabular}

Source: own survey data, 2020. ${ }^{* * *} p<0.01,{ }^{* * *} p<0.05,{ }^{* * *} p<0.1$, and ns $P>0.1$.

Farmers applied organic fertilizer for small plot crops, which are growing around their dwellings such as potato, maize, cabbage, and permanent crops (i.e., mango, coffee, and Gesho). However, they did not apply for Tef crops because it grows apart from their residence house and are covered in a large area. On the contrary, all respondents $(100 \%)$ applied inorganic fertilizer in their Tef plots (see Table 8). This implies that the majority of farmers in the study area applied inorganic fertilizer than organic fertilizer in their Tef plots.

Nowadays, Tef production is unimaginable without inorganic fertilizer. As provided in Table 9, from the total respondents, $98.66 \%$ and $100 \%$ applied urea and NPS/NPSB fertilizer, respectively. On the other hand, fertilizer adopter farmers have applied $71.43 \mathrm{~kg}$ urea ha ${ }^{-1}$ and $104.16 \mathrm{~kg}$ NPS/ NPSB ha ${ }^{-1}$ on average. This implies that Tef growers applied artificial fertilizer below the recommendation rate.

(1) Urea Fertilizer. In the study area, the recommendation rates of urea fertilizer for Nitosols and Vertisols Tef plots are $75 \mathrm{~kg} \mathrm{ha}^{-1}$ and $125 \mathrm{kgha}^{-1}$, respectively [13]. Sample households applied $51.87 \mathrm{~kg} \mathrm{ha}^{-1}$ and $89.82 \mathrm{~kg} \mathrm{ha}^{-1}$ urea for Nitosols and Vertisols, respectively. Low, medium, and high adopters applied $25 \mathrm{~kg} \mathrm{ha}^{-1}, 45.31 \mathrm{~kg} \mathrm{ha}^{-1}$, and $62.23 \mathrm{~kg} \mathrm{ha}^{-1}$ urea for Nitosols on average, respectively (see Table 10). Likewise, medium, and high adopters applied $77.27 \mathrm{~kg} \mathrm{ha}^{-1}$ and $100.19 \mathrm{~kg} \mathrm{ha}^{-1}$ urea for Vertisols, respectively. Respondents in the study area applied $51.87 \mathrm{~kg} \mathrm{ha}^{-1}$ and $89.82 \mathrm{~kg} \mathrm{ha}^{-1}$ urea on their Nitosols and Vertisols Tef plots on average, respectively. This implies that $\mathrm{Tef}$ grower farmers applied urea fertilizer below the recommendation rate. One-way ANOVA result shows that there is a significant mean difference between adopter categories in relation to the rate of urea fertilizer in both soil types at less than $1 \%$ level of significance.
TABle 8: Adoption of fertilizer.

\begin{tabular}{lcccc}
\hline \multirow{2}{*}{ Types of fertilizer } & \multicolumn{2}{c}{ Adopter } & \multicolumn{2}{c}{ Nonadopter } \\
& Freq. & $\%$ & Freq. & $\%$ \\
\hline Organic & 0 & 0.00 & 224 & 100.00 \\
Inorganic & 224 & 100.00 & 0 & 0.00 \\
Total & 224 & 100.00 & 224 & 100.00 \\
\hline
\end{tabular}

Source: own survey data, 2020.

(2) NPS/NPSB Fertilizer. The recommendation rate of NPS/ NPSB fertilizer for Tef is $125 \mathrm{~kg} \mathrm{ha}^{-1}$ and $150 \mathrm{~kg} \mathrm{ha}^{-1}$ for Nitosols and Vertisols, respectively. Sample households applied on average $110.47 \mathrm{~kg} \mathrm{ha}^{-1}$ and $97.19 \mathrm{~kg} \mathrm{ha}^{-1}$ NPS/ NPSB fertilizer for Nitosols and Vertisols, respectively (see Table 11). Low, medium, and high adopters applied $38.46 \mathrm{~kg} \mathrm{ha}^{-1}, 96.55 \mathrm{~kg} \mathrm{ha}^{-1}$, and $124.73 \mathrm{~kg} \mathrm{ha}^{-1}$ NPS/NPSB fertilizer for Nitosols, respectively. Similarly, medium and high adopters applied $95.57 \mathrm{~kg} \mathrm{ha}^{-1}$ and $119.50 \mathrm{~kg} \mathrm{ha}^{-1} \mathrm{NPS/}$ NPSB fertilizer for Vertisols, respectively. This implies that farmers in the study area apply NPS/NPSB below the recommendation rate. One-way analysis of variance (ANOVA) result indicates that there is a significant mean difference between adopter categories with regard to the rate of NPS/ NPSB fertilizer application at less than $1 \%$ level of significance.

3.2.4. Adoption of Plowing Frequency. Plowing is one of the crucial packages in Tef production. Its frequency varies from 2 to 4 times based on soil type and weed and pest infestation conditions. A mechanized plowing method is recommended for better plowing [13]. However, in the study area, mechanized plowing (i.e., tractor) is nonexistent at the farmer's level. As depicted in Table 12, sample 
TABle 9: Farmers' adoption status of inorganic fertilizer.

\begin{tabular}{|c|c|c|c|c|c|c|}
\hline Inorganic fertilizer & Adoption category & Freq. & Mean kg ha ${ }^{-1}$ & Std. dev. & Min & Max \\
\hline \multirow{3}{*}{ Urea } & Nonadopter & 3 & 0 & - & 0 & 0 \\
\hline & Adopter & 221 & 71.43 & 20.67 & 20 & 120 \\
\hline & Total & 224 & 70.47 & 22.12 & 0 & 120 \\
\hline \multirow{3}{*}{ NPS/NPSB } & Nonadopters & 0 & 0 & - & 0 & 0 \\
\hline & Adopters & 224 & 104.16 & 19.16 & 50 & 150 \\
\hline & Total & 224 & 104.16 & 19.16 & 50 & 150 \\
\hline
\end{tabular}

Source: own survey, 2020.

TABle 10: Farmers' adoption status of urea fertilizer.

\begin{tabular}{|c|c|c|c|c|c|c|}
\hline Soil type & Urea fertilizer adoption category & Freq. & $\%$ & Mean kg ha ${ }^{-1}$ & Std. dev. & $F$-test \\
\hline \multirow{5}{*}{ Nitosols } & Nonadopters & 2 & 1.23 & 0 & 0 & \multirow{5}{*}{$138.13^{* * *}$} \\
\hline & Low adopters & 2 & 1.23 & 25 & 0 & \\
\hline & Medium adopters & 88 & 53.99 & 45.31 & 6.00 & \\
\hline & High adopters & 71 & 43.56 & 62.23 & 7.42 & \\
\hline & Total & 163 & 100.0 & 51.87 & 12.47 & \\
\hline \multirow{5}{*}{ Vertisols } & Nonadopters & 10 & 6.13 & 0 & - & \multirow{5}{*}{$719.24^{* * *}$} \\
\hline & Low adopters & 0 & 0 & - & - & \\
\hline & Medium adopters & 30 & 18.40 & 77.27 & 5.76 & \\
\hline & High adopters & 123 & 75.46 & 100.19 & 9.05 & \\
\hline & Total & 163 & 100.0 & 89.82 & 26.01 & \\
\hline
\end{tabular}

Source: own survey data, 2020. ${ }^{* * *} p<0.01,{ }^{* *} p<0.05,{ }^{*} p<0.1$, and ns $P>0.1$.

TABLE 11: Farmers' adoption status of NPS/NPSB fertilizer.

\begin{tabular}{|c|c|c|c|c|c|c|}
\hline Soil type & NPS fertilizer adoption category & Freq. & $\%$ & Mean $\mathrm{kg} \mathrm{ha}^{-1}$ & SD & $F$-test \\
\hline \multirow{5}{*}{ Nitosols } & Nonadopters & 1 & 0.61 & 0 & - & \multirow{5}{*}{$114.85^{* * *}$} \\
\hline & Low adopters & 1 & 0.61 & 38.46 & - & \\
\hline & Medium adopters & 75 & 46.01 & 96.55 & 8.44 & \\
\hline & High adopters & 86 & 52.76 & 124.73 & 14.35 & \\
\hline & Total & 163 & 100 & 110.47 & 21.11 & \\
\hline \multirow{5}{*}{ Vertisols } & Nonadopters & 11 & 6.75 & 0 & 0 & \multirow{5}{*}{$893.04^{* * *}$} \\
\hline & Low adopters & 0 & 0 & - & - & \\
\hline & Medium adopters & 97 & 59.51 & 95.57 & 8.22 & \\
\hline & High adopters & 55 & 33.74 & 119.50 & 9.89 & \\
\hline & Total & 163 & 100.00 & 97.19 & 29.74 & \\
\hline
\end{tabular}

Source: own survey data, 2020. ${ }^{* * *} p<0.01,{ }^{* *} p<0.05,{ }^{*} p<0.1$, and ns $P>0.1$.

TABLE 12: Farmers' adoption status of plowing frequency.

\begin{tabular}{|c|c|c|c|c|c|}
\hline Plowing freq. adoption category & Obs & $\%$ & Plowing freq. plot $^{-1}$ & $\mathrm{SD}$ & $F$-test \\
\hline Nonadopters & 0 & 0 & - & - & $24.87^{* * *}$ \\
\hline Low adopters & 2 & 0.89 & 2.5 & 0 & \\
\hline Medium adopters & 3 & 1.34 & 2.5 & 0 & \\
\hline High adopters & 219 & 97.77 & 3.73 & 0.39 & \\
\hline Total & 224 & 100.00 & 3.71 & 0.42 & \\
\hline
\end{tabular}

Source: own survey data, 2020. ${ }^{* * *} p<0.01,{ }^{* *} p<0.05,{ }^{*} p<0.1$, and ns $P>0.1$.

households plowed their Tef plots using oxen 3.71 times plot $^{-1}$ with a standard deviation of 0.42 . This implies that farmers in the study area plow their Tef plots relatively based on the recommended frequency. Low, medium, and high adopters plowed their Tef plots on average 2.5 times

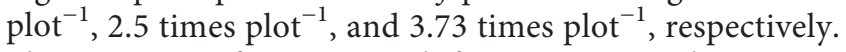
There is a significant mean difference across adopter categories in relation to plowing frequency at a $1 \%$ significant level.
3.2.5. Adoption of Weed Management. The management practice of weed remains one of the most tasks for Tef growers due to its poor competitive ability with weed. The manual weeding management method is recommended for Tef grower farmers [24]. According to Table 13, from the total respondents, $66.67 \%$ were used of manual-only weed control method, whereas the remaining $33.33 \%$ of the respondents used chemical and manual methods. This implies that in the study area, the majority of households manage 
TABLE 13: Methods of weed management.

\begin{tabular}{|c|c|c|c|c|c|c|c|c|}
\hline \multirow{2}{*}{ Weed management methods } & \multicolumn{2}{|c|}{ Adopter } & \multicolumn{2}{|c|}{ Nonadopter } & \multicolumn{4}{|c|}{ Total } \\
\hline & Freq. & $\%$ & Freq. & $\%$ & Freq. & $\%$ & Min & Max \\
\hline Only manual & 82 & 46.59 & 114 & 50.89 & 149 & 66.67 & 1 & 3 \\
\hline Only chemical & 0 & 0.00 & 0 & 0.00 & 0 & 0.00 & - & - \\
\hline Both manual and chemical & 94 & 53.41 & 110 & 49.11 & 75 & 33.33 & 1 & 2 \\
\hline Total & 224 & 100 & 224 & 100 & 224 & 100.00 & & \\
\hline
\end{tabular}

Source: own survey (2020).

their Tef plots based on the recommendation method (manually).

(1) Frequency of Manual Weeding Management per Plot. The recommendation frequency of the manually weeding control method is two to three times [13]. As shown in Table 14, of the total respondents, $47.32 \%$ of households were managed their Tef plots with a frequency below two, whereas 52.68\% managed two and above frequency using manual method. This implies that the majority of households practice manual weeding management based on the recommended frequency.

(2) Farmers Adoption Status of Weeding Frequency. As shown in Table 15, adopter farmers managed manually their Tef plots 1.75 times $\operatorname{plot}^{-1}$ on average with a standard deviation of 0.49 . Another notable result is that low, medium, and high adopters applied 1.12 times plot $^{-1}, 1.76$ times plot $^{-1}$, and 2.29 times plot ${ }^{-1}$ with manually weed control methods on average, respectively. This implies that farmers practice manual weed management methods based on the recommended frequency. One-way analysis of variance results indicated that there is a significant mean difference across adopter categories with regard to weeding frequency at a $1 \%$ level of significance.

3.2.6. Adoption of Crop Rotation. Crop rotation is another vital technology package in Tef production. The Ministry of Agriculture suggested farmers should not be planting Tef for two consecutive years on the same plot [22]. As shown in Table 16, sample households on average rotated their Tef plots 0.74 times plot $^{-1}$ with a standard deviation of 0.32 . Low, medium, and high adopters rotated their Tef plots 0.33 times plot $^{-1}, 0.55$ times plot $^{-1}$, and 0.97times plot $^{-1}$, respectively. On average, the respondents rotated their Tef plots 0.74 times. This implies that farmers in the study area practice monoculture production practice in consecutive cropping seasons. One-way analysis of variance results indicated that there is a significant mean difference across adopter categories with regard to crop rotation at a $1 \%$ level of significance.

3.2.7. Planting Method. Row planting by hand or machine at a row distance of $20 \mathrm{~cm}$ or transplanting at 10 to $15 \mathrm{~cm}$ between plants within a row is recommended to alleviate lodging and increase production and productivity of Tef [25]. Respondents in the study area were covered only 0.01 ha in a row planting method (see Table 17) from the
TABLE 14: Frequency of manual weeding management per plot.

\begin{tabular}{lcc}
\hline $\begin{array}{l}\text { Manual weeding management frequency } \\
\text { plot }^{-1}\end{array}$ & Frequency & Percentage \\
\hline Zero & 0 & 0.00 \\
Greater than zero and less than one & 3 & 1.34 \\
One and less than two & 103 & 45.98 \\
Two and above & 118 & 52.68 \\
Total & 224 & 100.00 \\
\hline
\end{tabular}

Source: own survey (2020).

average 0.47 ha Tef land (see Table 6). This implies that farmers in the study area seem to totally exclude the row planting method. This is because the row planting method is a backbreaker, labor-consuming, and lack of efficient row planter machine. The result is consistent with the findings of Joachim et al. [25]. One-way analysis of variance results indicated that there is a significant mean difference across adopter categories at a $1 \%$ level of significance.

3.2.8. Productivity of Tef in the Study Area. At the national level, the expected Tef production is $2,300 \mathrm{~kg} \mathrm{ha}^{-1}$ [26]. Table 18 shows survey respondents' of Tef production ha ${ }^{-1}$ during the 2019/20 cropping season. According to the table, the average $\mathrm{Tef}$ production $\mathrm{ha}^{-1}$ in the study area was $954.90 \mathrm{~kg} \mathrm{ha}^{-1}$. It is worthwhile notable that Tef production is very low in the district. As can be seen, adopters are exceeding $96 \mathrm{~kg} \mathrm{ha}^{-1}$ than nonadopter. Another notable result is that there is a significant production mean difference between adopters and nonadopters.

\subsection{Farmers' Perception towards Improved Tef Technology}

Packages. This part of the study was including the two core technology packages such as the improved Tef varieties and row planting technology packages.

\subsubsection{Farmers' Perception towards Improved Tef Varieties.} To obtain farmers' preference of Tef varieties, first, the list of attributes are identified, which helps farmers characterize the different varieties of Tef. This was done by consulting Tef seed multiplication cooperatives (i.e., Avolla Goshiye farmers' seed enterprise), research center (i.e., Adet research center), and kebele plant science experts and validating the information with farmers. The identified attributes were better grain yield, tolerance to disease, lodging tolerance, good germination, early maturity, and high straw quality. 
TABLE 15: Farmers' adoption status of weeding frequency.

\begin{tabular}{|c|c|c|c|c|c|}
\hline Adoption category of weeding freq. & Obs & $\%$ & Weeding freq. plot $^{-1}$ & SD & $F$-test \\
\hline Nonadopters & 0 & 0 & - & - & $89.38^{* * *}$ \\
\hline Low adopters & 33 & 14.73 & 1.12 & 0.32 & \\
\hline Medium adopters & 154 & 68.75 & 1.76 & 0.34 & \\
\hline High adopters & 37 & 16.52 & 2.29 & 0.48 & \\
\hline Total & 224 & 100.0 & 1.75 & 0.49 & \\
\hline
\end{tabular}

Source: own survey data, 2020. ${ }^{* * *} p<0.01,{ }^{* * *} p<0.05,{ }^{* * *} p<0.1$, and ns $P>0.1$.

TABLE 16: Adoption of crop rotation.

\begin{tabular}{lccccc}
\hline Adoption category of rotation freq. & Obs & $\%$ & Crop rotation plot $^{-1}$ & SD & \multicolumn{1}{c}{-test $^{-}$} \\
\hline Nonadopters & 20 & 8.93 & 0 & 0 & $743.92^{* * *}$ \\
Low adopters & 5 & 2.23 & 0.33 & 0.55 & 0.11 \\
Medium adopters & 69 & 30.80 & 0.97 & 0.10 \\
High adopters & 130 & 58.04 & 0.74 & 0.32 \\
Total & 224 & 100.00 & & \\
\hline
\end{tabular}

Source: own survey data, 2020. ${ }^{* * *} p<0.01,{ }^{* * *} p<0.05,{ }^{* * *} p<0.1$, and ns $P>0.1$.

TABLE 17: Farmers' adoption status of the Tef row planting method.

\begin{tabular}{lccccc}
\hline Adoption category of row planting & Obs & $\%$ & Mean land (ha) & SD & \multicolumn{1}{c}{-test } \\
\hline Nonadopters & 213 & 95.09 & 0 & 0.09 & 0.05 \\
Low adopters & 1 & 0.45 & 0.17 & 0.05 & 0.11 \\
Medium adopters & 6 & 2.68 & 0.42 & 0.06 \\
High adopters & 4 & 1.79 & 0.01 & \\
Total & 224 & & & \\
\hline
\end{tabular}

Source: own survey data, $2020 .{ }^{* * *} p<0.01,{ }^{* * *} p<0.05,{ }^{* * *} p<0.1$, and ns $P>0.1$.

TABle 18: Production of Tef per hectare.

\begin{tabular}{lccccccc}
\hline Adopter category & Obs & $\%$ & Production ha h $^{-1}(\mathrm{~kg})$ & SD & Min & Max & T-test \\
\hline Nonadopters & 48 & 21.43 & 879.29 & 137.66 & 600 & 1,200 & $-3.4^{* * *}$ \\
Adopters & 176 & 78.57 & 975.52 & 182.23 & 521 & 1,450 \\
Total & 224 & 100.00 & 954.90 & 177.82 & 521 & 1,450 \\
\hline
\end{tabular}

Source: own survey (2020).

(1) Improved versus Local Varieties. Table 19 shows the result of farmers' perception embodies in local and improved Tef varieties. As it can be seen, 89.73\%, 87.05\%, 59.38\%, 45.54\%, and $41.52 \%$ of the respondents perceived that improved seed is better in grain yield, germination, disease, early maturity, and tolerance to lodging than local Tef seed, respectively. However, $70.54 \%$ of the farmers perceived that the straw quality of local seed was better than the improved seed. This implies that attributes of improved Tef varieties are better than their counterpart local Tef varieties.

According to Figure 3, the respondents who agree with improved Tef variety have high yield, high disease resistance, early maturity, straw quality, and better germination were higher in adopter groups than nonadopter groups. When comparing adopter and nonadopter respondents with improved Tef varieties that have high lodging tolerance, the former one has a positive perception than the latter. The result shows that adopter groups in the study area perceived that improved Tef varieties are better than local varieties in different attributes. This implies that positive perceptions towards the technology has utmost importance to adopting the technology.

3.3.2. Farmers' Perception on Improved Tef Variety Attributes. Farmers' perception on the use of improved Tef technology is generally attached with the advantages of technology components. Farmers examine the advantages from the view of profitability and compatibility. Davis [27] suggested that the "degree to which a person believes that using a particular technology would enhance production" is a major factor that affects the acceptance of technology. Based on this farmers' perception on improved Tef varieties, they have been included in this study. Accordingly, ratings such as strongly agree (5), agree (4), undecided (3), disagree (2), and strongly disagree (1) were used to measure the respondents' perception of the technology. The value (5) indicates that how farmers perceived technology as highly positive, and values less than (3) show how farmers perceived the technology as negative or poor. According to 
TABLE 19: Farmers' perception on improved versus local Tef seed.

\begin{tabular}{|c|c|c|c|c|c|c|c|c|c|c|c|c|}
\hline & \multicolumn{2}{|c|}{ Better yield } & \multicolumn{2}{|c|}{$\begin{array}{l}\text { Disease } \\
\text { tolerance }\end{array}$} & \multicolumn{2}{|c|}{$\begin{array}{l}\text { Lodging } \\
\text { tolerance }\end{array}$} & \multicolumn{2}{|c|}{$\begin{array}{c}\text { Good } \\
\text { germination }\end{array}$} & \multicolumn{2}{|c|}{$\begin{array}{c}\text { High straw } \\
\text { quality }\end{array}$} & \multicolumn{2}{|c|}{ Early maturity } \\
\hline & Freq. & $\%$ & Freq. & $\%$ & Freq. & $\%$ & Freq. & $\%$ & Freq. & $\%$ & Freq. & $\%$ \\
\hline Local & 5 & 2.23 & 54 & 24.11 & 77 & 34.38 & 8 & 3.57 & 158 & 70.54 & 14 & 6.25 \\
\hline The same & 18 & 8.04 & 37 & 16.52 & 54 & 24.11 & 21 & 9.38 & 60 & 26.79 & 108 & 48.21 \\
\hline Improved & 201 & 89.73 & 133 & 59.38 & 93 & 41.52 & 195 & 87.05 & 6 & 2.68 & 102 & 45.54 \\
\hline Mean & \multicolumn{2}{|c|}{2.87} & \multicolumn{2}{|c|}{2.35} & \multicolumn{2}{|c|}{2.07} & \multicolumn{2}{|c|}{2.83} & \multicolumn{2}{|c|}{1.32} & \multicolumn{2}{|c|}{2.39} \\
\hline Std. dev. & \multicolumn{2}{|c|}{0.39} & \multicolumn{2}{|c|}{0.84} & \multicolumn{2}{|c|}{0.87} & \multicolumn{2}{|c|}{0.45} & \multicolumn{2}{|c|}{0.52} & \multicolumn{2}{|c|}{0.60} \\
\hline
\end{tabular}

Source: computed from own survey, 2020.
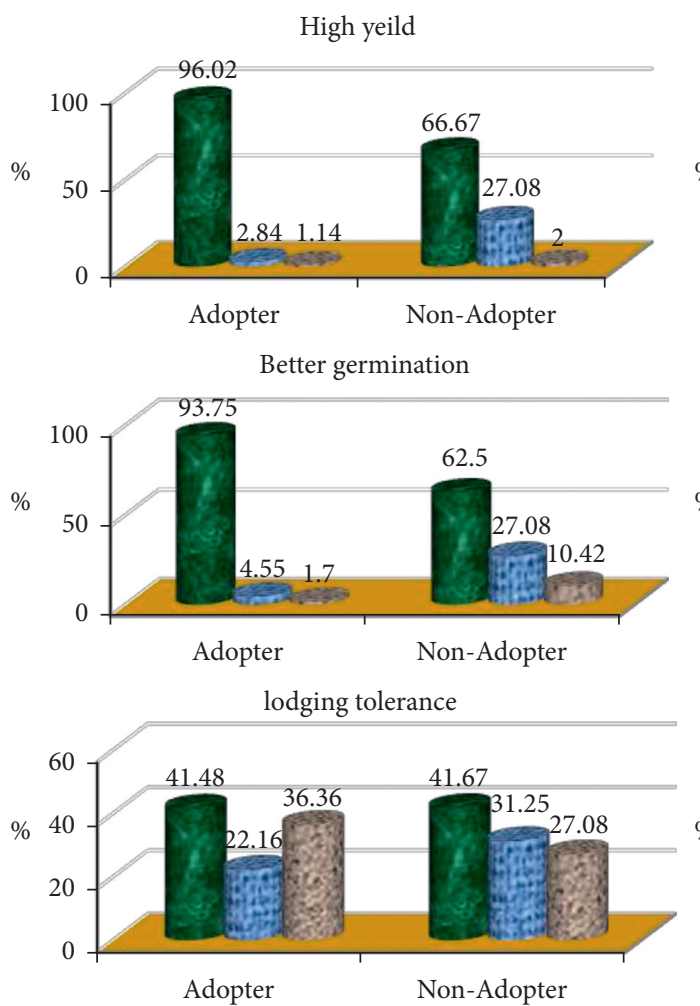

Source: Computed from own survey, 2020

Improved Seed is better

Fin The same

毁 Local seed is better

Figure 3: Farmers' perception towards improved versus local Tef varieties.
High disease resistance

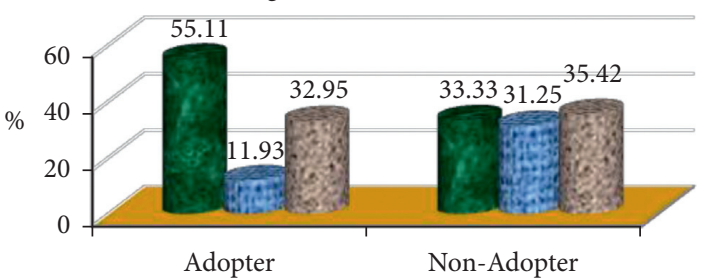

High straw quality
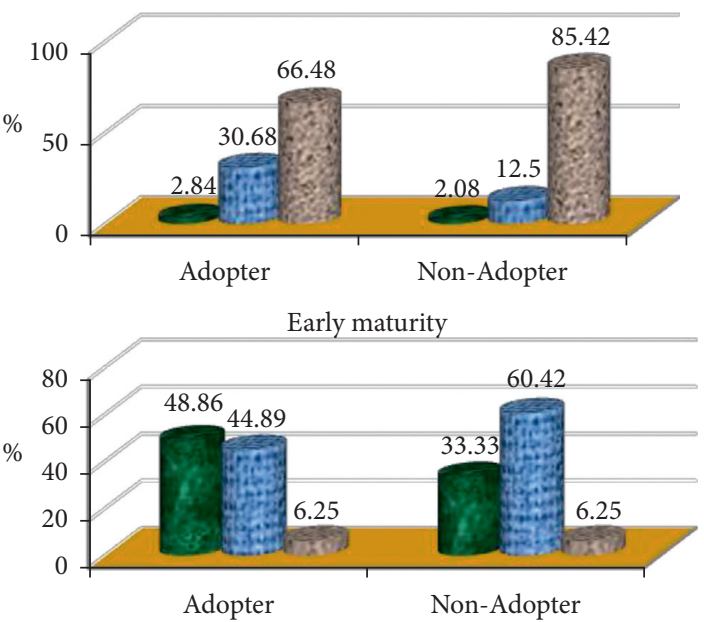

TABLE 20: Farmers' perception on improved Tef variety attributes.

\begin{tabular}{|c|c|c|c|c|c|c|c|}
\hline \multirow[t]{2}{*}{ Attributes of improved Tef varieties } & \multicolumn{5}{|c|}{$\begin{array}{l}\text { Distribution of respondents based on the perception } \\
\text { of improved Tef varieties (frequency) }\end{array}$} & \multirow[t]{2}{*}{ Item mean } & \multirow[t]{2}{*}{ Std. dev. } \\
\hline & SA & A & ND & $\mathrm{D}$ & SD & & \\
\hline Grain yield is better & 151 & 57 & 14 & 1 & 1 & 4.58 & 0.67 \\
\hline Early mature & 5 & 97 & 108 & 14 & 0 & 3.41 & 0.64 \\
\hline Good germination & 35 & 164 & 22 & 3 & 0 & 4.03 & 0.55 \\
\hline High disease resistance & 2 & 110 & 37 & 54 & 21 & 3.08 & 1.06 \\
\hline High straw quality & 11 & 13 & 53 & 64 & 83 & 2.12 & 1.12 \\
\hline High lodging tolerance & 36 & 56 & 65 & 63 & 4 & 2.74 & 1.08 \\
\hline Sum of the mean & & & & & & 19.88 & \\
\hline Grand mean & & & & & & 3.31 & \\
\hline
\end{tabular}

Source: own survey 2020. SA = strongly agree; $\mathrm{A}=$ agree; $\mathrm{ND}=$ no decision; $\mathrm{SD}=$ strongly disagree; $D=$ disagree. 
TABLE 21: Relative importance index of improved Tef varieties.

\begin{tabular}{lccc}
\hline Items & Attributes & RII & Rank \\
\hline 1 & High grain yield & 0.917857 & 1 st \\
2 & Early mature & 0.714286 & 3rd \\
3 & Good germination & 0.80625 & 2nd \\
4 & Disease resistance & 0.616071 & 4 th \\
5 & Better straw quality & 0.425893 & 6 th \\
6 & High tolerance to lodging & 0.549107 & 5 th \\
\hline
\end{tabular}

Source: computed from own survey (2020).
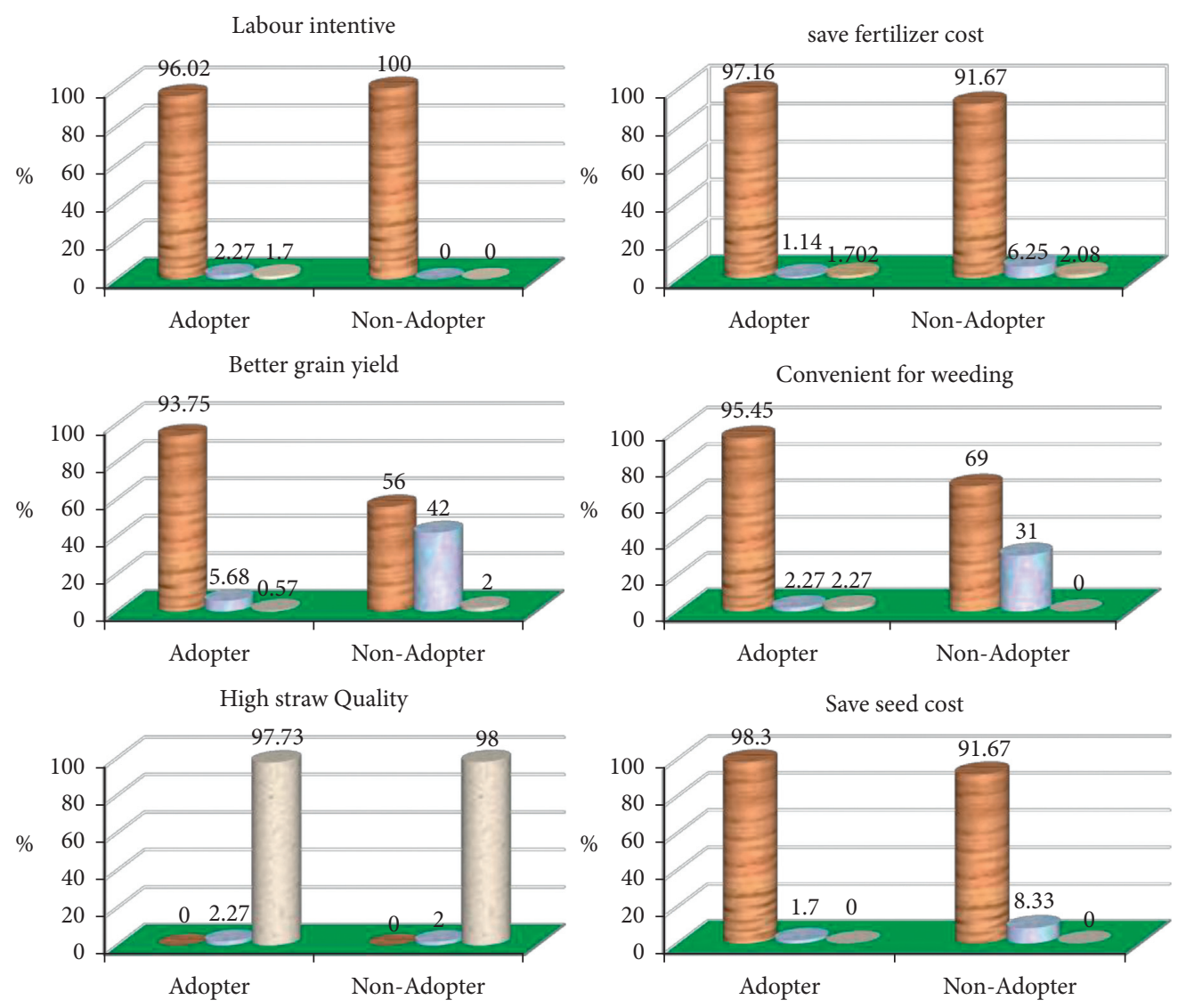

Consume time
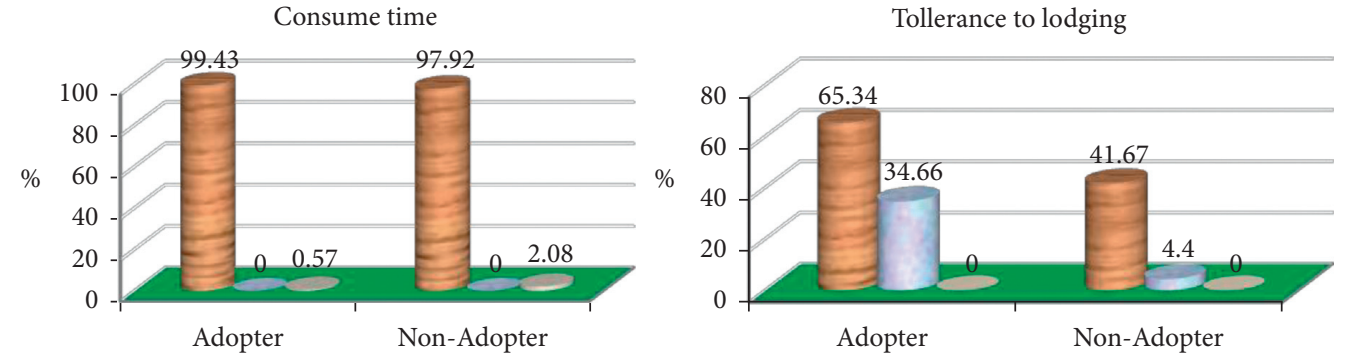

Source: Computed from own survey, 2020

n Row is better

든 The same

III Broadcast is better

FIgURE 4: Farmer's perception towards Tef row versus broadcast planting method. 
TABLE 22: Farmers' perception towards row planting method.

\begin{tabular}{|c|c|c|c|c|c|c|c|}
\hline \multirow[t]{2}{*}{ Attributes of row planting method } & \multicolumn{5}{|c|}{$\begin{array}{l}\text { Distribution of respondents based on the perception of } \\
\text { Tef row planting (frequency) }\end{array}$} & \multirow[t]{2}{*}{ Item mean } & \multirow[t]{2}{*}{$\mathrm{SD}$} \\
\hline & SA & A & ND & $\mathrm{D}$ & $\mathrm{SD}$ & & \\
\hline \multicolumn{8}{|l|}{ Relative advantage } \\
\hline High yield & 158 & 37 & 27 & 27 & 0 & 4.56 & 0.73 \\
\hline Reduce seed cost & 154 & 63 & 7 & 0 & 0 & 4.65 & 0.53 \\
\hline Reduce fertilizer cost & 150 & 65 & 5 & 1 & 3 & 4.59 & 0.68 \\
\hline Tolerance to lodging & 18 & 117 & 42 & 25 & 22 & 3.37 & 1.10 \\
\hline Convenient for weeding & 125 & 84 & 15 & 0 & 0 & 4.49 & 0.62 \\
\hline Total mean & & & & & & 21.66 & \\
\hline Grand mean & & & & & & 4.33 & \\
\hline \multicolumn{8}{|l|}{ Relative disadvantage } \\
\hline Consume high labor & 190 & 32 & 2 & 0 & 0 & 4.82 & 0.50 \\
\hline Time consume & 170 & 52 & 0 & 0 & 2 & 4.73 & 0.55 \\
\hline Low straw quality & 160 & 56 & 4 & 3 & 1 & 4.65 & 0.63 \\
\hline Total mean & & & & & & 14.2 & \\
\hline Grand mean & & & & & & 4.73 & \\
\hline
\end{tabular}

Source: own survey (2020). $\mathrm{SA}=$ strongly agree, $\mathrm{A}=$ agree, $\mathrm{ND}=$ no decision, $\mathrm{SD}=$ strongly disagree, and $D=$ disagree.

Table 20, the grand mean (3.31) shows that the overall perception of the respondents based on the given attributes was positive. The result also shows that farmers' perceptions on straw quality (2.12) and lodging tolerance (2.74) capacity were negative. Negative perception for straw quality of improved Tef varieties could be because farmers need soft and weak straw for livestock feeding, but the quality of improved seed straw is strong. This result is consistent with Regasa et al. [28] and Dawit and Gemechu [21].

\subsubsection{Relative Importance of the Attributes of Improved Tef} Variety. As shown in Table 21, six Likert scale items were included to measure the relative importance of improved Tef varieties. Accordingly, the relative importance index was developed to determine which items were very highly important and of less importance. The result shows that high grain yield, good germination, early maturity, disease resistance, high tolerance to lodging, and better straw quality for livestock feeding ranks first to sixth, respectively. This implies that tolerance to lodging and straw qualities are less important attributes of improved Tef variety.

\subsubsection{Farmers' Perception towards Row Planting Method.} As illustrated in Figure 4, farmers in the study area perceived that the Tef row planting method is labor-intensive, consumes more time, and has low straw quality for livestock feeding than the broadcast method. Moreover, farmers perceived these attributes as demerits of the row planting method. However, they perceived that row planting has a high grain yield, is convenient for weeding, saves fertilizer cost, reduces seed rate, and has high tolerance to lodging than the broadcast planting method. Surprisingly, farmers perceived that row planting has paramount importance to boost Tef yield by reducing competition between Tef plants for water, light, and nutrients. Eventually, Figure 3, shows the comparison between adopter and nonadopter farmers with relation to perception towards row planting method.
TABLE 23: Relative importance and disadvantage index of row planting method.

\begin{tabular}{lccc}
\hline Item & Attributes & RII & Rank \\
\hline \multicolumn{4}{c}{ Relative advantage } \\
1 & Convenient for weeding & 0.898214 & 4 \\
2 & Better yield & 0.913393 & 3 \\
3 & Tolerance to lodging & 0.675 & 5 \\
4 & Reduce seed cost & 0.93125 & 1 \\
5 & Reduce fertilizer cost & 0.919643 & 2 \\
\hline \multicolumn{4}{c}{ Relative disadvantage } \\
1 & Consume high labor & 0.964286 & 1 \\
2 & Low straw quality & 0.93125 & 3 \\
3 & Consume time & 0.946429 & 2 \\
\hline
\end{tabular}

Source: computed from own survey (2020).

To measure farmers' perception towards the row planting method, 5 and 3 Likert scale statements were included (see Table 22). The result shows that reduced seed cost, reduced fertilizer cost, high grain yield, convenience for weeding, and tolerance to lodging were perceived by the farmers as a relative advantage with item mean of 4.65, 4.59, $4.56,4.49$, and 3.37 , respectively. On the other hand, high labor and time consumption and low straw qualities were perceived as a relative disadvantage with item mean of 4.82 , 4.73 , and 4.65 , respectively. The grand mean (4.33) of relative advantage shows that the overall perception of the respondents with relative advantages of the row planting method is positive. On the other hand, the grand mean (4.73) of relative disadvantage shows that the overall perception of the respondents with a relative disadvantage of row planting was highly negative.

3.3.5. Relative Importance Index of Row Planting Method. As shown in Table 23, eight Likert scale items were included to measure farmers' perception towards relative importance and disadvantage of the Tef row planting method. From the advantage side of Tef row planting method, reduce seed cost, reduce fertilizer cost, high grain yield, convenient for 
weeding, and tolerance to lodging are ranked from first to fifth, respectively. On the other hand, from the disadvantage side, consume high labor, time-consuming, and low straw quality are ranked from first to third, respectively.

\section{Conclusion and Recommendations}

The findings verify that farmers in the study area were found at the medium level of adoption of Tef production technology (i.e., the average adoption index is 0.43 ). The findings also confirm that farmers perception towards the relative advantages shows that high grain yield, good germination, early mature, and disease resistance capacity were perceived by the farmers as the most crucial attributes of improved Tef varieties, whereas straw quality and tolerance to lodging were perceived as the least important of attributes of the technology. The findings also verify that even if farmers perceived that Tef row planting method has a high yield, reduces the quantity of seed and fertilizer costs, and has convenience for weeding, but time consumption, low straw quality, and high labor consumption nature of the technology are major bottlenecks to apply Tef row planting method.

The most crucial issues in the Tef row planting method are the high labor and time consumption nature of the technology. Due to this reason, farmers prefer the broadcast planting method even if they accepted high yield and convenience for field management attributes of the technology. Therefore, the Ministry of Agriculture of Ethiopia, particularly the Amhara Region Bureau of Agriculture, and Yilmana Densa District Office of Agriculture should avail easy, efficient, and least time; low labor consumer; and costeffective row planter technology for the farmers. According to the finding of this inquiry, farmers perceived lodging tolerance attributes of improved Tef varieties as the least important. They also raised this attribute as a major bottleneck for their Tef production process. Therefore, the efforts and the commitments of plant breeders and genetic specialists to develop $T e f$ varieties would help reduce lodging Tef through hybridizing semidwarf Tef varieties. The postharvest practice of Tef technology can be future research priority.

\section{Data Availability}

The data used to support the findings of this study are available from the first author upon request using atrsawanteneh0918@gmail.com.

\section{Conflicts of Interest}

The authors declare that there are no conflicts of interest regarding the publication of this paper.

\section{Acknowledgments}

The authors are grateful to the development agents and farmers of three kebeles (Debremawi, Goshiye, and Agita) in the East Gojjam zone that were sampled in this study.

\section{References}

[1] B. Minten, J. Vandercasteelen, A. Seyoum, and M. Dereje, Summary of ESSP Working Paper 60, Scaling-Up Adoption of Improved Technologies: The Impact of the Promotion of Row Planting on Farmers' Teff Yields in Ethiopia, p. 344, 2013.

[2] ATA, Addis Ababa, The New Agricultural Input Sale System, p. 22, 2018.

[3] WB (World Bank), Annual Population Growth Rate by Country, WB (World Bank), Washington, DC, USA, 2020.

[4] CSA Agricultural Sample Survey, "2018/19, Report on area and production of major crops I: (private peasant holdings, meher season)," Statistical Bulletin, vol. 589, p. 54, 2019.

[5] A. Miretu and L. Abebaw, "Scale-wide evaluation and promotion of improved Tef technologies under dryland scenario: economic profitability, farmers preference and constraints in Northeast Amhara, Ethiopia," Cogent Food and Agriculture, vol. 6, no. 1, pp. 1-19, 2020.

[6] A. Yami, "Tef Straw: A Valuable Feed Resource to Improve Animal Production and Productivity," in Proceedings of the Paper presented at the 2nd international workshop on tef improvement: Achievements and prospects, pp. 233-251, Debre Zeit, Ethiopia, November 2011.

[7] M. Melaku, M. Zarnkow, and T. Becker, “Teff (Eragrostis Tef) as a raw material for malting, brewing, and manufacturing of gluten-free foods and beverages: review," Journal of Food Science \& Technology, vol. 51, no. 11, pp. 2881-2895, 2014.

[8] D. J. Alain, M. Karen, and S. Elisabeth, Learning for Adopting: Technology Adoption in Developing Country Agriculture, FERDI, France, 2016.

[9] A. Bekele, S. Chanyalew, and T. Damtie, "Cost-benefit analysis of new Tef (eragrostis Tef) varieties under lead farmers' production management in the Central Ethiopia," Ethiopian Journal of Agricultural Sciences, vol. 29, no. 1, pp. 109-123, 2019.

[10] G. B. Allan, Elementary Statistics step by step approach, McGraw-Hill, New York, NY, USA, 2007.

[11] C. R. Kothari, Research Methodology Methods and Techniques, p. 401, New Age International (P) Ltd., Publishers, New Delhi, India, 2004.

[12] T. Abatneh, Factors Influencing Adoption of Improved Tef Technology Package: in Yilmana Densa District, Amhara Region, Bahir Dar University, Bahir Dar, Ethiopia, 2020.

[13] ATA \& EIAR, Fogera, Amhara National Regional State Bureau of Agriculture 2011/12 E.C Tef (Eragrostis Tef (Zucc.) Trotter) Production Manual, Amhara National Regional State, Fogera, Ethiopia, 2019.

[14] M. Arega, Determinants of Intensity of Adoption of Old Coffee Stumping Technology in Dale Woreda, SNNPRS, Haramaya University, Ethiopia, 2009.

[15] W. Mekuria and D. Tadesse, "Determinants affecting adoption of malt-barley technology: evidence from North Gonder, Ethiopia," Journal of Food Security, vol. 3, no. 3, pp. 75-81, 2015.

[16] O. Lydia Olufunmilola, S. Adebayo, and A. Sunday, "Factors influencing levels and intensity of adoption of new rice for Africa (Nerica) among rice farmers in Ogun state, Nigeria," International Journal of Agricultural Economics, vol. 2, no. 3, pp. 84-89, 2017.

[17] J. Olumide Ilesanmi and J. Atanda Afolabi, "Determinants of adoption of improved Cocoa technologies in Ekiti state, Nigeria," International Journal of Agricultural Economics, vol. 5, no. 2, pp. 36-42, 2020. 
[18] O. P. Akadiri, Development of a Multi-Criteria Approach for the Selection of Sustainable Materials for Building Projects, $\mathrm{PhD}$ Thesis, University of Wolverhampton, Wolverhampton, UK, 2011.

[19] E. Gedefaw, Determinants of Adoption of Improved Maize BH540 Variety Among Smallholder Farmer: The Case of Dera Woreda, South Gonder Zone, University of Gonder, Gondar, Ethiopia, 2019.

[20] B. Tegegne and S. Teshome, "Determinants of adoption of improved teff varieties by smallholder farmers: the case of Kobo district, north wollo zone, Amhara region, Ethiopia," International Journal of Agricultural Economics, vol. 5, no. 4, pp. 114-122, 2020.

[21] D. Mikias and G. Beri, “Assessing farmer's perception towards improved Quncho teff varity in gindeberet district, west shoawa zone, oromia region Ethiopia," Journal of Plant Sciences, vol. 8, no. 5, pp. 106-111, 2020.

[22] T. Zigale, T. Girma, T. Douglas, and V. Hugo, Adoption of Improved Bread Wheat Varieties and Inorganic Fertilizer by Small-Scale Farmers in Yilmana Densa and Farta Districts of Northwestern Ethiopia, DF, Mexico, 2001.

[23] H. Tefera, A. Mulu, and K. Assefa, Improved Varieties of Tef (Eragrostis Tef) in Ethiopia: Releases of 1970-1995, Research Gate, Debre Zeit Ethiopia, 1995.

[24] T. Bogale, S. Jemal, Y. Abera, M. Liben, and W. Mazengia, Crop Management Research for Tef, in Proceedings of the Second International Workshop, pp. 107-120, Debre Zeit, Ethiopia, November 2011.

[25] J. Vandercasteelen, B. Minten, A. Seyoum, and M. Dereje, Summary of ESSP Working Paper 65 Perceptions, Impacts and Rewards of Row Planting of Teff, International Food Policy Research Institutes, Washington DC, USA, 2014.

[26] D. Alemu, S. Rashid, and T. Robert, Seed System Potential in Ethiopia: Constraints and Opportunities for Enhancing the Seed Sector, International Food Policy Research Institutes, Washington DC, USA, 2010.

[27] D. Fred, "Perceived usefulness, perceived ease of use, and user acceptance of information technology," MIS Quarterly, vol. 26, 1989.

[28] R. Dibaba, A. Hagos, C. Yirga, and E. Habte, "Determinants of improved teff varieties adoption and its impact on productivity: the case of non-traditional teff growing areas of western Ethiopia," Journal of Natural Sciences Research, vol. 8, no. 22, pp. 55-67, 2018. 